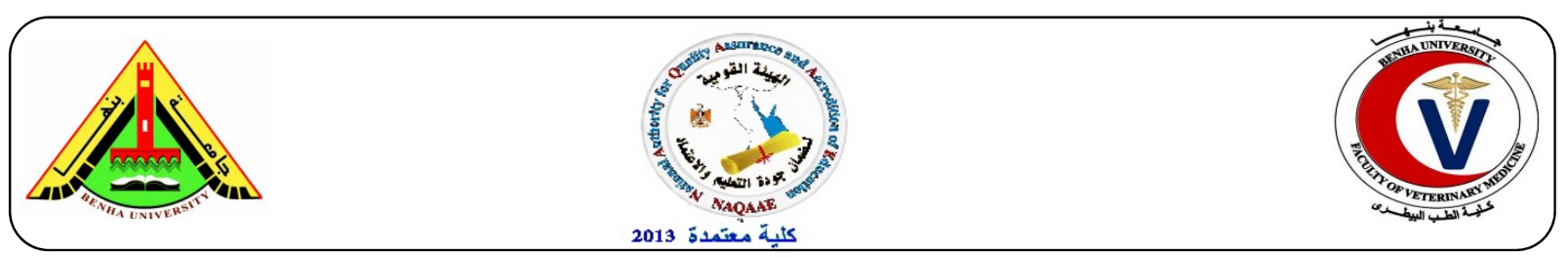

\title{
Traceability of enteropathogenic $E$. coli in cattle and camel carcasses
}

\author{
Hassan, M.A. ${ }^{1}$, Heikal, G.I. ${ }^{2}$ and Barhoma, R.M. ${ }^{3}$ \\ ${ }^{1}$ Food hygiene Department, faculty of veterinary medicine, Benha University. \\ ${ }^{2}$ Animal Health Research Institute, Tanta Branch. \\ ${ }^{3}$ Environment Management, Al Qaliubiya Governorate.
}

\begin{abstract}
A B S T R A C T
A total of 120 random samples of cattle and camel carcasses (60 $0 \mathrm{f}$ each) were collected from the different abattoirs located in Qaliubiya governorate. The samples taken from each carcass were represented meat, spleen, liver and kidneys (15 samples of each), the samples were collected directly after slaughtering and evisceration. The collected samples were subjected to bacteriological examination for detection and identification of E. coli. Enteropathogenic E. coli organisms were $6.67 \%, 20 \%, 26.67 \%$, and $40 \%$ of the examined samples of cattle meat, spleen, liver and kidney respectively and were $0.0 \%, 13.33 \%, 13.33 \%$, and $33.33 \%$ of the examined samples of camel meat, spleen, liver and kidney respectively. The isolated strains were investigated by using Multiplex PCR to detect presence of virulent genes (stx1, stx2 and eaeA) in each isolated Strain of E. coli. $\mathrm{O}_{15}$ Positive strain for stx2 gene, $\mathrm{O}_{26} \& \mathrm{O}_{111}$ Positive strains for stx1, stx2 and eaeA genes. $\mathrm{O}_{44} \& \mathrm{O}_{126}$ Positive strains for stx 1 gene. $\mathrm{O}_{55}$ Positive strain for stx2 gene and eaeA genes. $\mathrm{O}_{91}, \mathrm{O}_{103}$ \& $\mathrm{O}_{127} P_{0 s i t i v e}$ strains for stx 1 and stx2 genes $\mathrm{O}_{124}$ negative strains for stx1, stx2 and eaeA genes. The public health importance of the isolated E. coli and the possible sources of contamination of cattle and camel carcasses with E. Coli as well as suggestive hygienic measures to improve the quality of carcasses were discussed.
\end{abstract}

KEYWORDS: E. Coli, cattle, camel, carcasses, PCR.

(http://www.bvmj.bu.edu.eg)

(BVMJ-31(1): 50-55, 2016)

\section{INTRODUCTION}

Meat is considered as an important source of proteins and essential amino acids. Due to this rich composition, it offers a highly favorable environment for the growth of pathogenic bacteria. The microbiological contamination of carcasses occurs mainly during processing and handling, such as skinning, evisceration, storage and distribution at slaughterhouses and retail establishments (Gill, 1998 and Abdalla et al., 2009). The microbial quality of meat depends up on the physiological status of the animal at slaughter, the spread of contamination during slaughter and processing, the temperature and other conditions of storage during distribution (Nychas et al., 2008).

Escherichia coli is considered the most commensally living microorganism in the alimentary tract of nearly all domestic and wild animals as well as human. Enteropathogenic E. coli organisms usually lead to severe diarrhea in infants and it may also be the causal organisms in appendicular abscess, peritonitis and cholecystitis (Frazier and Westhoff, 1988 and Mackie and McCartney, 1989). The presence of E. coli is thought to give an indication of faecal contamination (enteric pathogens in particular) than the entire group of Enterobacteriaceae. (Kagambèga et al., 2011). The food-borne pathogens are grouped into the following categories based on distinct virulence properties, different interactions with intestinal mucosa, distinct clinical syndromes differences in epidemiology and distinct O:H serogroups: Enteropathogenic E.coli (EPEC), Enteroinvasive E.coli(EIEC), Enterotoigenic E.coli(ETEC), Enterohaemorrhagic E.coli (EHEC) and Verocyto-toxigenic E.coli (VTEC) (FAO and WHO, 1991).

Shiga toxin (stx) producing E.coli (STEC) was among the most common causes of food-borne diseases. The role of non $\mathrm{O}_{157}$ STEC strains (e.g., $\mathrm{O}_{26}: \mathrm{H}_{11} / \mathrm{H}, \mathrm{O}_{91}: \mathrm{H}_{21} / \mathrm{H}, \mathrm{O}_{103}: \mathrm{H}_{2}, \mathrm{O}_{111}: \mathrm{H}, \mathrm{O}_{113}: \mathrm{H}_{21}$, $\mathrm{O}_{121}: \mathrm{H}_{19}, \mathrm{O}_{128}: \mathrm{H}_{2} / \mathrm{H}$, and $\left.\mathrm{O}_{145}: \mathrm{H}_{28} / \mathrm{H}\right)$ as causes of HUS, bloody diarrhea, and other gastrointestinal illnesses was being increasingly recognized. (Ursula et al., 2012 and Son et al., 2014). The different $E$. coli serovars which isolated from different meat products by multiplex PCR with 
specific primers for Stx1, Stx2 and eae genes revealed the presence or absence of these genes in the tested isolates. The obtained results showed that the isolates E. coli $\mathrm{O}_{111}$ and $\mathrm{O}_{26}$ proved to have the three genes (Stx1, Stx2 and eaeA genes), Meanwhile $\mathrm{O}_{119}$ isolates were positive for Stx 1 and Stx2 genes. In addition, O86 isolates had onlyStx2 (Shawish, 2015). E. coli causes illness ranging from gastrointestinal tract-related complications such as diarrhea, dysentery, urinary tract infection, pneumonia and even meningitis (Johnson et al., 2006).

\section{MATERIALS AND METHODS}

\subsection{Collection of samples}

A total of 120 random samples of cattle and camel carcasses (60 of each) were collected from the different abattoirs located in Qaliubiya governorate. The samples taken from each carcass were represented meat, spleen, liver, and kidneys (15 samples of each). Each sample was kept in a separated sterile plastic bag and preserved in an ice box then transferred to the laboratory under complete aseptic conditions without undue delay and examined as quickly as possible. The collected samples were subjected to bacteriological examination to detect $E$. coli.

\subsection{Preparation of samples: (ICMSF. 1982).}

Twenty five gms were taken aseptically from the examined meat, spleen, liver and kidney samples and transferred aseptically to a sterile homogenizer bag containing $225 \mathrm{mls}$ of sterile peptone water (1\%) and homogenized for 2.5 minute at 3000 r.p.m. to provide a diluation 101, then decimal serial dilutions were prepared.

\subsection{Screening of Enteropathogenic Escherichia coli (APHA, 1984 and ICMSF, 1996).}

\subsubsection{Pre-enrichment:}

One $\mathrm{ml}$ from the original dilution was inoculated into MacConky broth tube supplemented with inverted Durham's tube. The inoculated and control tube were incubated at $37^{\circ} \mathrm{C} / 24-48 \mathrm{hrs}$. Tubes showing gas production were considered positive for coliforms.

\subsubsection{Enrichment:}

One $\mathrm{ml}$ from positive MacConkey broth was transferred into Brilliant Green Bile 2\% broth tubes supplemented with inverted Durham's tube and incubated at $44 \pm 0.5^{\circ} \mathrm{C}$ for 18 hours (Eijkman test).

\subsubsection{Selective plating:}

A loopful from a positive Brilliant Green Bile (2\%) broth tube was streaked into Eosine Methylene Blue agar (EMB) incubated at $37^{\circ} \mathrm{C} / 24$; typical colonies of $E$. coli appear greenish metallic with purple center.

\subsubsection{Identification of Escherichia coli:}

Microscopical examination: Gram negative coccobacilli to medium size rods.

Biochemical identification: Motility test: + ve result (non-motile) (MacFaddin, 2000). Indol production test: + ve result (red ring) (MacFaddin, 2000). Methyl Red reaction: + ve result (red colour) (Ljutov, 1961). Voges Proskaure test: -ve result (no change in color) (Ljutov, (1963). Gelatin Liquefacrion: -ve result (Collins, 1984). Hydrolysis of urea: -ve result (no change in color) (Edwards, and Ewing, 1972 and Krieg, N.R. and Holt, J.G., 1984). Hydrogen sulphide test: -ve result (no change in colour) (Krieg, and Holt, 984). Utilization of citrate: -ve result (no change in colour) (MacFaddin, 1976). Fermentation of sugars: +ve result with lactose (MacFaddin, 1976). Eijkman test: E. coli is one of few organisms that produce gas at this temperature (APHA. (1984).

\subsubsection{Serological identification:}

The isolates were serologically identified according to (Simmon, 1926), by using rapid diagnostic E. coli antisera sets (Denka Seiken Co., Japan) for diagnosis of the enteropathogenic types.

\subsection{Polymerase Chain Reaction (PCR):}

\subsubsection{Materials used for PCR:}

Reagents used for agarose gel electrophoresis: Agarose powder, Biotechnology grade (Bioshop ${ }^{R}$, Canda inc. lot No: OE16323). It prepared in concentration $2 \%$ in $1 \times$ TAE buffer. Tris acetate EDTA (TAE) electrophoresis buffer (50×liquid concentration) (Bioshop ${ }^{\mathrm{R}}$, Canada inc. lot No: 9E11854). The solution diluted to $1 \times$ by adding 1 $\mathrm{ml}$ stock solution to $49 \mathrm{ml}$ double dist. Water to be used in the preparation of the gel or as a running buffer. Ethidium bromide solution (stock solution) biotechnology grade (Bioshop ${ }^{\circledR}$ Canda Inc, Lot No: 0A14667): The stock solution was diluted by $25 \mu \mathrm{l} / 200 \mathrm{ml}$ double distilled water and stored covered at $4^{\circ} \mathrm{C}$. It was used for staining of PCR products that electrophoreses on agarose gel to be visualized by UV light.

Gel loading buffer ( $6 \times$ stock solution) (Fermentas, lot No: ooo56239). The components were dissolved in sterile double distilled water and stored covered with aluminum foil at room temperature. DNA ladder (molecular marker): 100 bp (Fermentas, lot No: 00052518). 5X Taq master (Fermentas): Containing 
polymerase enzyme, Magnesium chloride $\left(\mathrm{Mg} \mathrm{Cl}_{2}\right)$, Deoxy nucleotide triphosphate (dNTP) and PCR grade water. Primer sequences of $E$. coli used for PCR identification system: Application of PCR for identification of shiga toxins (stx1 \& stx2) and intimin (eaeA) genes of E. coli was performed essentially by using Primers (Pharmacia Biotech) as follow:

\begin{tabular}{llll}
\hline Target gene & Oligonucleotide sequence $\left(5^{\prime} \rightarrow 3^{\prime}\right)$ & Product size $(\mathrm{bp})$ & References \\
\hline stx1 (F) & 5' ACACTGGATGATCTCAGTGG '3 & & Dhanashree and Mallya (2008) \\
Stx1 (R) & 5' CTGAATCCCCCTCCATTATG '3 & 614 & \\
Stx2 (F) & 5' CCATGACAACGGACAGCAGTT '3 & & Dhanashree and Mallya (2008) \\
Stx2 (R) & 5' CCTGTCAACTGAGCAGCACTTTG '3 & 779 & \\
eaeA (F) & 5' GTGGCGAATACTGGCGAGACT '3 & & Jeshveen et al. (2013) \\
eaeA (R) & 5' CCCCATTCTTTTTCACCGTCG '3 & 890 & \\
\hline
\end{tabular}

\subsubsection{DNA preparation from bacterial culture (Kok et al., 1996)}

After overnight culture on nutrient agar plates, one or two colonies were suspended in $20 \mathrm{ml}$ of sterile distilled water, and the suspension was then heated at $100^{\circ} \mathrm{C}$ for 20 minutes. From this suspension, a $5 \mu \mathrm{l}$ aliquot was directly used as a template for PCR amplification.

\subsubsection{DNA amplification:}

Amplification reaction of E. coli (Shah et al., 2009). The amplification was performed on a Thermal Cycler (Master cycler, Eppendorf, Hamburg, Germany) using $25 \mu 1$ of PCR mixture containing $3 \mu \mathrm{l}$ of boiled cell lysate, $250 \mu \mathrm{M}$ of each desoxynucleotide triphosphate, $1.5 \mathrm{U}$ of Taq DNA polymerase (Biotools, Madrid, Spain), buffer $(20 \mathrm{mM}$ Tris- $\mathrm{HCl} \mathrm{pH} \mathrm{8.4,50} \mathrm{mM} \mathrm{KCl}$ and $3 \mathrm{mM} \mathrm{MgCl} 2$, Biotools), $1 \mu \mathrm{M}$ of the primers mecA-R, mecA-F; $0.8 \mu \mathrm{M}$ of icaA-R, icaA-F and $0.8 \mu \mathrm{M}$ of icaD-R, icaD-F. Amplification conditions were: denaturation for $3 \mathrm{~min}$ at $94^{\circ} \mathrm{C}$, followed by 30 cycles of $94^{\circ} \mathrm{C}$ for $1 \mathrm{~min}, 58^{\circ} \mathrm{C}$ for $1 \mathrm{~min}$ and $72^{\circ} \mathrm{C}$ for $1 \mathrm{~min}$, with final extension at $72^{\circ} \mathrm{C}$ for $5 \mathrm{~min}$. Amplified products were analyzed by $1.5 \%$ of agarose gel electrophoresis stained with ethidium bromide and visualized and captured on UV transilluminator.

\section{RESULTS}

Table (1) indicated that Enteropathogenic E. coli organisms were $6.67 \%, 20 \%, 26.67 \%$, and $40 \%$ of the examined samples of cattle meat, spleen, liver and kidney respectively. The identified serovars of pathogenic E.coli were $\mathrm{O}_{111}: \mathrm{H}_{2}(6.67 \%)$ for cattle meat, $\mathrm{O}_{91}: \mathrm{H}_{21}, \mathrm{O}_{111}: \mathrm{H}_{2}, \mathrm{O}_{127}: \mathrm{H}_{6}(6.67 \%$ for each) in cattle spleen, $\mathrm{O}_{26}: \mathrm{H}_{11}(13.33 \%)$ and $\mathrm{O} 44$ : $\mathrm{H} 18, \mathrm{O}_{103}: \mathrm{H}_{2}\left(6.67 \%\right.$ for each) in cattle liver, $\mathrm{O}_{127}$ $: \mathrm{H}_{6}(13.33 \%)$ and $\mathrm{O}_{15}, \mathrm{O} 26: \mathrm{H}_{11}, \mathrm{O}_{111}: \mathrm{H}_{2}, \mathrm{O}_{124}$ (6.67\% for each) in cattle kidney.

Table (2) indicated that Enteropathogenic E.coli organisms were $0.0 \%, 13.33 \%, 13.33 \%$, and $33.33 \%$ of the examined samples of camel meat, spleen, liver and kidney respectively. The identified serovars of pathogenic E.coli were $\mathrm{O}_{26}$ : $\mathrm{H}_{11}, \mathrm{O}_{126}: \mathrm{H}_{21}(6.67 \%$ for each) in camel spleen, $\mathrm{O}_{55}: \mathrm{H}_{7}, \mathrm{O}_{111}: \mathrm{H}_{2}(6.67 \%$ for each) in camel liver, $\mathrm{O}_{111}: \mathrm{H}_{2}(13.33 \%), \mathrm{O}_{26}: \mathrm{H}_{11}, \mathrm{O}_{91}: \mathrm{H}_{21}, \mathrm{O}_{126}: \mathrm{H}_{21}$ (6.67\% for each), in camel kidney.

Photo (1) showed agarose gel electrophoresis of multiplex PCR of stx 1 (614 bp), stx2 (779 bp) and eaeA (890 bp) genes for characterization of Enteropathogenic E. coli. showed that, $10 \mathrm{E}$. coli strains E. coli $\mathrm{O}_{15}, \mathrm{O}_{26}, \mathrm{O}_{111}, \mathrm{O}_{44}, \mathrm{O}_{126}, \mathrm{O}_{55}, \mathrm{O}_{91}$, $\mathrm{O}_{103}, \mathrm{O}_{127} \& \mathrm{O}_{124}$, investigated by multiplex PCR to detect presence of virulence genes st $x 1, s t \times 2$ and intimin (eaeA), From the recorded results it was found that $E$. coli $\mathrm{O}_{15}$ Positive strain for stx2 gene, E. coli $\mathrm{O}_{26} \& \mathrm{O}_{111}$ Positive strains for stx1, stx2 and eaeA genes. E. coli $\mathrm{O}_{44} \& \mathrm{O}_{126}$ Positive strains for stx 1 gene. E. coli $\mathrm{O}_{55}$ Positive strain for stx 2 gene and eaeA genes. E. coli $\mathrm{O}_{91}, \mathrm{O}_{103} \& \mathrm{O}_{127}$ Positive strains for stx 1 and stx 2 genes. While $E$. coli $\mathrm{O}_{124}$ considered negative strain for stx 1 , stx2 and eaeA genes. The strains which were positive for eaeA gene which encodes intimin, an important binding protein of pathogenic STEC as $E$. coli $\mathrm{O}_{26}$, $\mathrm{O}_{111}, \mathrm{O}_{55}$ and $\mathrm{O}_{125}$ more virulent than other strains not carry this gene and considered more toxigenic and hazardous to consumer health. 
Table (1): Incidence and serotyping of Enteropathogenic E. coli isolated from the examined samples of cattle meat and offal $(n=15)$.

\begin{tabular}{|c|c|c|c|c|c|c|c|c|c|}
\hline \multirow{2}{*}{$\begin{array}{l}\text { Tissues } \\
\text { E.coli Strains }\end{array}$} & \multicolumn{2}{|c|}{ Meat } & \multicolumn{2}{|c|}{ Spleen } & \multicolumn{2}{|c|}{ Liver } & \multicolumn{2}{|c|}{ Kidney } & \multirow{2}{*}{$\begin{array}{l}\text { Strain } \\
\text { Characteristics }\end{array}$} \\
\hline & No. & $\%$ & No. & $\%$ & No. & $\%$ & No. & $\%$ & \\
\hline O15 & - & - & - & - & - & - & 1 & 6.67 & EPEC \\
\hline O26 : H11 & - & - & - & - & 2 & 13.33 & 1 & 6.67 & EHEC \\
\hline O44: H18 & - & - & - & - & 1 & 6.67 & - & - & EPEC \\
\hline O91 : H21 & - & - & 1 & 6.67 & - & - & - & - & EHEC \\
\hline $\mathrm{O} 103: \mathrm{H} 2$ & - & - & - & - & 1 & 6.67 & - & - & EHEC \\
\hline $\mathrm{O} 111: \mathrm{H} 2$ & 1 & 6.67 & 1 & 6.67 & - & - & 1 & 6.67 & EHEC \\
\hline $\mathrm{O} 124$ & - & - & - & - & - & - & 1 & 6.67 & EIEC \\
\hline O127 : H6 & - & - & 1 & 6.67 & - & - & 2 & 13.33 & ETEC \\
\hline Total & 1 & 6.67 & 3 & 20 & 4 & 26.67 & 6 & 40 & \\
\hline
\end{tabular}

Table (2): Incidence and serotyping of Enteropathogenic E. coli isolated from the examined samples of camel meat and offal $(n=15)$.

\begin{tabular}{|c|c|c|c|c|c|c|c|c|c|}
\hline \multirow{2}{*}{$\begin{array}{r}\text { Tissues } \\
\text { E. coli strains }\end{array}$} & \multicolumn{2}{|c|}{ Meat } & \multicolumn{2}{|c|}{ Spleen } & \multicolumn{2}{|c|}{ Liver } & \multicolumn{2}{|c|}{ Kidney } & \multirow{2}{*}{$\begin{array}{l}\text { Strain } \\
\text { Characteristics }\end{array}$} \\
\hline & No. & $\%$ & No. & $\%$ & No. & $\%$ & No. & $\%$ & \\
\hline $\mathrm{O} 26: \mathrm{H} 11$ & - & - & 1 & 6.67 & - & - & 1 & 6.67 & EHEC \\
\hline O55: H7 & - & - & - & - & 1 & 6.67 & - & - & EPEC \\
\hline O91 : H21 & - & - & - & - & - & - & 1 & 6.67 & EHEC \\
\hline $\mathrm{O} 111: \mathrm{H} 2$ & - & - & - & - & 1 & 6.67 & 2 & 13.33 & EHEC \\
\hline $\mathrm{O} 126: \mathrm{H} 21$ & - & - & 1 & 6.67 & - & - & 1 & 6.67 & ETEC \\
\hline Total & - & - & 2 & 13.33 & 2 & 13.33 & 5 & 33.33 & \\
\hline
\end{tabular}

\section{$\begin{array}{lllllllllllll}M & 1 & 2 & 3 & 4 & 5 & 6 & 7 & 8 & 9 & 10 & 11 & 12\end{array}$}

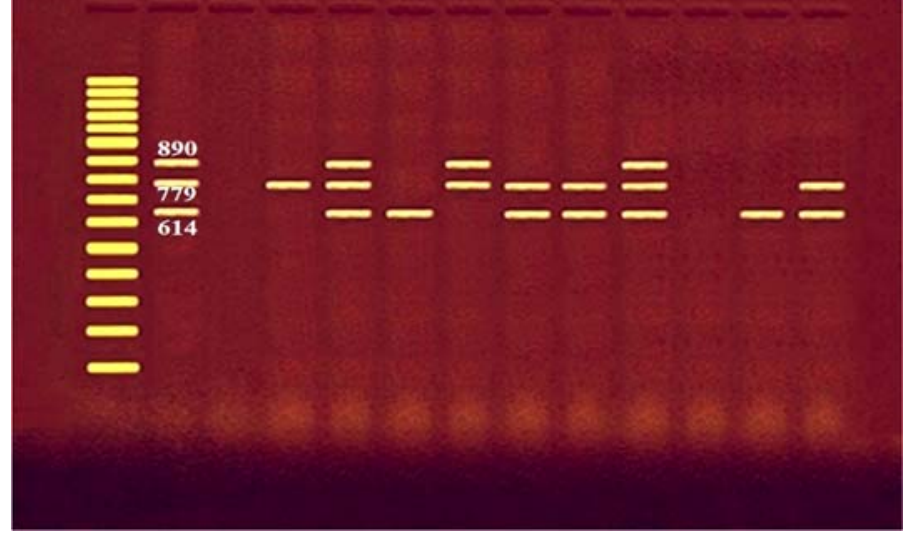

Photograph (1): Agarose gel electrophoresis of multiplex PCR of stx1 (614 bp), stx2 (779 bp) and eaeA (890 bp) genes for characterization of Enteropathogenic E. coli. Lane M: 100 bp ladder as molecular size DNA marker. Lane 1: Control positive E. coli for stx1, stx2 and eaeA genes. Lane 2: Control negative. Lane 3 (E. coli $\mathrm{O}_{15}$ ): Positive strain for stx2 gene. Lanes 4 \& 9 (E. coli $\mathrm{O}_{26} \& \mathrm{O}_{111}$ ): Positive strains for stx 1 , stx 2 and eaeA genes. Lanes $5 \& 11$ (E. coli $\mathrm{O}_{44} \& \mathrm{O}_{126}$ ): Positive strains for stx 1 gene. Lane 6 (E. coli $\mathrm{O}_{55}$ ): Positive strain for stx2 gene and eaeA genes. Lanes 7, 8 \& 12 (E. coli $\left.\mathrm{O}_{91}, \mathrm{O}_{103} \& \mathrm{O}_{127}\right)$ : Positive strains for stx 1 and stx2 genes. Lane $10\left(\right.$ E. coli $\left.\mathrm{O}_{124}\right)$ : negative strains for stx 1 , stx 2 and eaeA genes. 


\section{DISCUSSION}

The food-borne pathogens are grouped into the following categories based on distinct virulence properties, different interactions with intestinal mucosa, distinct clinical syndromes differences in epidemiology and distinct O:H serogroups: Enteropathogenic E. coli (EPEC), Enteroinvasive E. coli (EIEC), Enterotoigenic E. coli (ETEC), Enterohaemorrhagic E. coli (EHEC) and Verocyto-toxigenic E. coli (VTEC) (FAO and WHO, 1991). The achieved results (table1\&2) are nearly similar to those obtained by (Abdalla et al., 2009) who examined a total of 384 swab samples (rump, brisket, neck and shoulder) from cattle carcasses and found that E. coli $(8.86 \%)$. Higher results recorded by (Mohamed - amany, 2010) examined 40 liver samples 20 livers each from cattle and camels, E. coli could be isolated at rates of $35 \%$ for cattle, and $25 \%$ for camels. Escherichia coli could be seriologically identified as $\mathrm{O}_{26}, \mathrm{O}_{127}$, $\mathrm{O}_{111}, \mathrm{O}_{143}, \mathrm{O}_{128}$. (El-Shamy, 2011) the incidence of E. coli isolated out of 25 examined liver samples were $40 \%, 7(28 \%)$ Enteropathogenic, $2(8 \%)$. Enterohaemorrhagic and 1 sample (4\%) Enterotoxigenic. (Roushdy et al., 1983) who examined 50 liver samples obtained from healthy slaughtered cattle and isolated E. coli $(42 \%)$ and by (Salem-Ghada, S. 2001) who collected offal samples from butcher's shop and street cars and isolated E. coli at $(40 \%)$ and $(60 \%)$ in liver samples respectively. (Al-Rhodn 2010) examined 25 liver from slaughtered cows E.Coli presence was confirmed biochemically in $53.3 \%$ of liver isolates. Enterohemolytic activity was detected in liver. (Wahba 2006) recorded the percentages of E. coli on the examined carcass surfaces (fore quarter, hind quarter and brisket) were $55 \%, 60 \%$ and $55 \%$, respectively.

In general, EPEC strains are the major cause for many infantile diarrhea, in typical cases, symptoms appear within 12 to 36 hours. Clinically, EPEC illness is characterized by fever, nausea, vomition and watery stools, which occasionally contain mucous, but without gross blood (Jay, 1997). Furthermore, EPEC was implicated in cases of gastroenteritis, cystitis, colitis, pyelonephritis, and peritonitis as well as food poisoning outbreaks (Sumner et al., 2003). Therefore, EPEC showed to be the first bacterial cause of diarrhea in infants and its proportion may reach 54\% (Varnam and Evans, 1991). Though, numerous research efforts have been made during the past decades and in recent years for food borne pathogen detection. Therefore, a detection technique which is reliable, rapid, accurate, simple, sensitive, selective and cost effective has to be developed. In addition, it should be able to detect pathogens in very low concentrations of the samples and must be suitable for in situ real-time monitoring (Arshak et al., 2010).

Application of multiplex PCR for detection of non-O157: H7 STEC virulence genes as (stx1, stx2, eae, hly, etpD, katP6) not only improve the detection efficiency but also increase the accuracy and mentioned that traditional detection approaches for non-O157 STEC are both time and labor consuming in diseases surveillance (Wang et al., 2013).

\section{REFERENCES}

Abdallah, M.A., Suliman, S.E., Ahmed, D.E. and Bakhiet, A.O. 2009. Estimation of bacterial contamination of indigenous bovine carcasses in Khartoum (Sudan). Afri. J. Microbio. Res., 3(12):882-886.

Al-Rhodan, A. M. 2010. Isolation and identification of Enterohemolytic E.Coli from slaughtered cow's Liver and lung. Bas. J. vet. Res. , 9 (1): 59-64.

APHA. 1984. Compendium of methods for microbiological examination of foods. 2nd Ed., Am. Public Health Assoc. New York, Washington, DC.

Arshak, K., Vijayalakshmi, V., Olga, K. and Kamila, O. 2010. An overview of food borne pathogen detection: In the perspective of biosensors Biotechnology Advances 28: 232-254.

Collins, C.H. 1984. Microbiological methods 5th Ed. Microbiology laboratory manual, Bri. Library. Butter Worth in Co.

Edwards, P.R. and Ewing, W.H. 1972. Identification of Enterobacteriaceae. Minneapolis, Burgress, publ. Comp., Atlanta, U.S.A.

El-Shamey, R. H. 2011. Quality assurance of internal edible offal produced from food animal abattoirs in Alexandria. Ph.D. Thesis, Fac. Vet. Med. Alex. Univ. Egypt.

FAO/WHO 1991. Food and Agriculture Organization / World and Health Organization W.H.O surveillance program for central of food borne infection and intoxication in Europe. Newsletter No 27 April Publisher by F.A.O / W.H.O. collaborating center for research and training in food hygiene and zoonosis of the federal institute for health Protection of consumers and Vet. Med., (BGVV) Berlin.

Frazier, W.C. and Westhoff, D. C. 1988. Food Microbiology. 4th Edn., McGraw-Hill International Editions Food Science Series, pp: 401.

Gill, C.O. 1998. Microbiological contamination of meat during slaughter and butchering of cattle, sheep and pigs. In: Davies, A.R., Board, R.G. (Eds.), The Microbiology of Meat and Poultry. Blackie Academic, London, pp. 118-157. 
ICMSF 1982. International Commission on Microbiological Specification for Foods. Microorganisms in Foods. 2nd Ed., Univ., Tronto Press, Toronto, 188-192.

ICMSF 1996. International Commission and Microbiological Specification for Foods. Salmonellae. In: Roberts, T. A., Baird-Parker, A. C., and Tompkin, R. B. eds. Microorganisms in foods 5: Microbiological specifications of food pathogens. $1^{\text {st }}$ Ed, Blackie Academic \& Professional, London, UK, pp 217-264.

Jay, J. M. 1997. Modern Food Microbiology. $4^{\text {th }}$ Ed. Chapman and Hall, International Thomson Publishing, New York.

Johnson, J., Kuskowki, M., Menard, M., Gajewski, A., Xercavins, M., Garau, J. 2006. Similarity between human and chicken Escherichia coli isolates in related to ciprofloxins resistance status. Infect. Dis., 194(1): 71- 78.

Kagambèga, A., Martikainen, O., Lienemann, T., Siitonen, A., Traoré, A.S., Barro, N. and Haukka, K. 2011. Diarrheagenic Escherichia coli detected by 16-plex PCR in raw meat and beef intestines sold at local markets in Ouagadougou, Burkina Faso. Inter. J. Food Microbiol., 153: 154- 158.

Kok, T.; Worswich, D. and Gowans, E. 1996. Some serological techniques for microbial and viral infections. In: Practical Medical Microbiology (Collee, J.; Fraser, A.; Marmion, B. and Simmons, A., eds.), 14th ed., Edinburgh, Churchill livingstone, UK.

Krieg, N.R. and Holt, J.G. 1984. Bergey's manual of systematic bacteriology. Vol.1.William and Wilkins Co., Baltimore, London.

Ljutov, V. 1961. Technique of methyl red test. Acta Pathological. Microbiol. Scand., 51(4): 369-380.

Ljutov, V. 1963. Technique of Voges Proskauer test. Acta Pathological. Microbiol. Scand., 58(3) :325-335

MacFaddin, F. 1976. Biochemical tests of identification medical bacteria. Waverly presses Inc. Baltimore Md., 21202 U.S.A.

MacFaddin, F. 2000. Biochemical tests of identification medical bacteria. $3^{\text {rd }}$ Ed., chapter 6 Medical Bacteria, 1. Williams \& Wilkins, Baltimore, MD.

Mackie, K. J. and McCartney, J.C. 1989. Medical Microbiology. Vol. 1 and 2, 30th Edn., Churchill Living Stone, Edinburg London Melbourne and New York.

Mohamed - Amany 2010. Microbiological studies on livers of cattle, buffaloes and camels Ph.D.
Thesis, Fac. Vet. Med. Cairo. Univ. Egypt.

Nychas, G. J. E., Skandamis, P. N., Tassou, C. C. and Koutsoumanis, K. P. 2008. Meat spoilage during distribution. J. Meat Sci., 78:77-89.

Roushdy, S, Hamdy, M. and Morshdy, A. 1983. Microflora in livers from slaughtered healthy cattle.Vet. Med.J., 31(3):189 -200.

Salem - Ghada, S. 2001. Sanitary status of meat and offal in public districts Ph.D. Thesis, Fac. Vet. Med. Cairo. Univ. Egypt.

Shah, D., Shringi, S., Besser, T. and Call, D. 2009. Molecular detection of foodborne pathogens, Boca Raton: CRC Press, In Liu, $\quad$ D. (Ed). Taylor \& Francis group, Florida, USA, Pp. 369389.

Shawish, R. R. M. 2015. Prevalence of shiga toxinproducing Escherichia coli in some beef products. Ph.D. Thesis (Meat Hygiene)., Fac. Vet. Med., Menoufia Univ. (Sadat branch). Egypt.

Simmon, J.S. 1926. A culture medium for differentiating the typhoid aerogenes group and for isolation of certain fungi. J. Infect. Dis., 39 (3):209 -214.

Son.; Binet, R., Maounounen, L. A., Lin, A. and Hammack, T. S. 2014. Detection of five Shiga toxin-producing Escherichia coli genes with multiplex PCR. Food Microbiol., 40: 31-40.

Sumner, J., Petrenas, E., Dean, P., Dowsett, P., West, G., Wiering, R. and Raven, G. 2003. Microbial Contamination on beef and sheep carcasses in South Australia. International Journal of Food Microbiology. 81. 255-260.

Ursula, K., Herbet, H., Nicole, G., Lothar, B. and Roger, S. 2012. "Human infections with non- $\mathrm{O}_{157}$ Shiga Toxin- producing Escherichia coli". Emerging Infectious Disease J.17:2.

Varnam, A. H. and Evans,M. G. 1991. Salmonella. In: Foodborne pathogens. An illustrated text. Eds: Varnam A.H. and Evans M.G. Wolfe Publishing Ltd, Aylesbury, England.

Wahba, A.K.A. 2006. Surface microbial contamination of calf buffalo carcasses slaughtered in an abattoir in Giza Governorate. Ph.V.Sc. Thesis Vet. Med., Moshtohor, Benha University. Egypt.

Wang, X. G., Zhang, Y. H., Chen, X. H., Luo, L. F., Liu, Y., Liu, J. Q., Song, C. P. and Chen G. Q. 2013. Establishment and application of multiplex PCR for non-O157: H7 STEC virulence genes detection. Zhonghua Shi Yan He Lin Chuang Bing Du Xue Za Zhi. (Article in Chinese). 27(5):388-391. 